\title{
Pendidikan Multikultural dalam Perspektif Islamic Worldview
}

\author{
Iqbal Amar Muzaki \\ Universitas Singaperbangsa, Karawang \\ Email: iqbalamar. muzakki@gmail. com \\ Ahmad Tafsir \\ Program Pascasarjana, Institut Agama Islam Darussalam (IAID) Ciamis, Jawa Barat \\ Email: ahmad. tafsiriaid@gmail.com \\ Received: December 16, 2017 | Accepted: March 17, 2018
}

\begin{abstract}
The research aims to elaborate the concept of multicultural education in the perspective of the Islamic worldview. Research using content analysis methods. A number of books, journal articles, proceeding articles, and other articles published in various media, studied and analyzed. Educational experts have always held that multicultural education is able to address social, political, and cultural problems. Their views are based on the belief that multicultural education essentially carries themes of respect and respect for other people's cultures, respect and empathy for diversity, tolerance, willingness to live together peacefully, willingness to share. This article attempts to highlight the concept of multicultural education in the perspective of an Islamic worldview.
\end{abstract}

\begin{abstract}
Abstrak
Penelitian bertujuan untuk mengelaborasi konsep pendidikan multikultural dalam perspektif pandangan dunia Islam. Penelitian menggunakan metode analisis isi. Sejumlah buku, artikel jurnal, artikel prosiding, dan artikel-artikel lain yang dimuat di berbagai media, dikaji dan dianalisis. Selama ini, banyak pakar yang berpandangan bahwa pendidikan multikultural mampu mengatasi problem sosial di bidang sosial, politik, dan budaya. Karena pendidikan multikultural pada hakikatnya mengusung tema-tema penghormatan dan penghargaan terhadap budaya orang lain, respek dan empati terhadap perbedaan, toleran, kesediaan untuk hidup bersama secara damai, kesediaan untuk berbagi. Artikel ini mencoba menyoroti konsep pendidikan multikultural dalam perspektif pandangan dunia Islam.
\end{abstract}

\section{Keywords}

Islamic education, multicultural education, Islamic worldview 


\section{Pendahuluan}

Dalam perspektif agama Islam sebagaimana dijelaskan dalam Al-Qur'an, sudah menjadi fitrah (bawaan) atau tabîaat al-kaun manusia diciptakan oleh Allah berbeda. Namun dalam pandangan Islam, perbedaan tersebut lantas tidak menjadi tolak ukur kemuliaan seseorang, berbeda dengan beberapa agama semisal agama Hindu. Dalam agama Hindu dikenal dengan beberapa kasta, kasta tersebut yang kemudian menjadi tolak ukur atau standar kemuliaan seseorang. Brahma menginterpretasikan golongan pendeta atau rahib dan kedudukannya sangat mulia. Kesatria adalah golongan pemerintah atau pahlawan-pahlawan, Waisya adalah golongan petani yang memiliki derajat di bawahnya, dan Sudra adalah golongan budak. Dalam agama Kristen, dikenal dengan dosa warisan, artinya bayi yang baru lahirpun tak lepas dari dosa, dosa yang diperbuat oleh kedua orang tuanya. Dogma kristen tersebut menjadi indikator bahwa manusia dalam pandangannya, sekalipun masih bayi bisa mencapai derajat yang rendah bila kemudian orangtuanya banyak menanggung dosa.

Dalam sudut pandang Islam, perbedaan yang merupakan sebuah keniscayaanbukanlah merupakan hal yang substantif. Justru dari perbedaan tersebut manusia diharapkan saling mengenal satu samalain, dan tidak menjadi standar kemuliaan. Yang menjadi standar kemuliaan dalam agama Islam adalah ketakwaannya. Seperti yang dikatakan Allah dalam QS Al-Hujurat ayat 13:

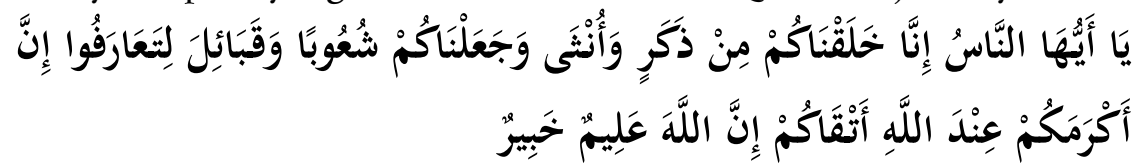

Hai manusia, sesungguhnya Kami menciptakan kamu dari seorang laki-laki dan seorang perempuan dan menjadikan kamu berbangsa - bangsa dan bersuku-suku supaya kamu saling kenal-mengenal. Sesungguhnya orang yang paling mulia diantara kamu disisi Allah ialah orang yang paling taqwa diantara kamu. Sesungguhnya Allah Maha Mengetahui lagi Maha Mengenal. (QS Al-Hujurat (49): 13)

Terkait dengan ayat tersebut, Ibnu Katsir menjelaskan bahwa dalam hal kemuliaan, seluruh umat manusia dipandang dari sisi ketanahannya dengan Adam dan Hawa adalah sama. Hanya saja kemudian mereka itu bertingkattingkat jika dilihat dari sisi-sisi keagamaan, yaitu ketaatan kepada Allah SWT dan kepatuhan mereka kepada Rasul-Nya. Oleh karena itu, setelah melarang berbuat ghibah dan mencaci sesama, (pada ayat sebelumnya-pen) Allah mengingatkan bahwa mereka itu sama dari sisi kemanusiaan (Katsir, 2013, p. 132).

Lain hal jika kita mengacu kepada pendapat kelompok agama yang memiliki pemahaman Pluralis, Liberalis, dan Sekularis, mereka memiliki 
kerangka pemikiran sebaliknya, memandang semua manusia beserta aspek keagamaannya sama. Apapun agamanya, apapun keyakinannya, mereka pantas mendapatkan tempat terbaik di sisi Tuhan. Sehingga muncul pemahaman semua agama benar, semua agama menuju Tuhan yang sama, jadi apapun agamanya selama ia berbuat baik, maka ia pasti mendapatkan surga. Sebuah pemahaman yang justru akan membuat umat tidak meyakini akan kebenaran agamanya. Katolik misalnya, semula punya doktrin Extra Ecclesium Nulla Salus (di luar Katholik tidak ada keselamatan), sebuah doktrin eksklusif yang diyakini sebagian besar kaum katolik. Kemudian teologi Inklusif muncul dikalangan mereka dan menilai bahwa teologi Ekslusif sudah ketinggalan zaman. Sehingga pada konsili Vatikan II (1962-1965) atas kesepakatan para uskup dan pendeta yang terjangkit virus pluralis, doktrin Katolik yang awalnya Extra Ecclesium Nulla Salus berubah menjadi Teologi "Inklusif Pluralis" yang mengandung makna diluar Katolik dimungkinkan masih ada kebenaran dan keselamatan.

Budhy Munawar Rachman mengatakan bahwa tantangan teologis paling besar dalam kehidupan beragama sekarang ini adalah bagaimana seorang beragama bisa mendefinisikan dirinya di tengah agama-agama lain. Atau istilah yang lebih teknis yang bisa dipakai dalam literatur teologi kontemporerbagaimana bisa berteologi dalam konteks agama-agama. Ada semacam hal yang terlalu dipaksakan oleh Budhi dalam wacana pluralitas agama. Dia seolah menjustifikasi bahwa ada semacam kebingungan di masyarakat tentang penempatan ranah agama dalam pluralitas (Rachman, 2001, p. ix). Dia mengatakan, pada tingkat teologis- yang merupakan dasar dari agama itu muncul kebingungan-kebingungan, khususnya menyangkut bagaimana kita harus mendefiniskan diri di tengah agama-agama lain yang juga eksis, dan punya keabsahan. Padahal teologi lama telah di set-up dan sejarah kemudian mengesktrimkannya dalam suatu kondisi non pluralitas: Bahwa hanya agamakulah yang paling benar, yang lain salah atau telah menyimpang. Belum lagi soal sosial politik yang sering, tiba-tiba memunculkan ketegangan dan kekerasan, seperti peristiwa-peristiwa yang meletus dalam penampakan konflik antar agama (Rachman, 2001, p. ix).

Budhy Munawar Rachman mengajak orang-orang untuk memahaminya dengan semangat Inklusivisme, semangat "Agama Universal" dimana Islam diberi makna sebagai agama yang penuh kepasrahan kepada Allah SWT. Sehingga semua agama bisa dimasukan ke dalamnya, asalkan berpasrah diri kepada Allah (Amien, 2015, p. 63). Muhammad Ali juga mengajak agar tidak memahami QS Ali Imran ayat 19 dan 85 itu dalam bingkai teologi ekslusif yakni keyakinan bahwa jalan kebenaran dan keselamatan bagi manusia hanyalah dapat dilalui melalui Islam. Ayat-ayat itu harus dipahami harus 
dipahami dengan teologi pluralis dan teologi inklusif. Nurcholis Madjid yang merupakan salah seorang tokoh pengusung teologi Pluralisme dalam kata pengantar buku "Pluralitas Agama Kerukunan Dalam Keragaman" menyatakan: "kendatipun cara, metoda atau jalan keberagamaan menuju Tuhan berbeda-beda, namun Tuhan yang hendak kita tuju adalah Tuhan yang sama, Allah yang Maha Esa". Kalimat ini jelas menunjukkan bahwa ia mengakui keberadaan dan kebenaran semua agama, dan menyejajarkan satu agama dengan agama lainnya, sehingga Islam sama dengan Kristen, Yahudi, Hindu, Budha, Majusi, Shintho, Konghuchu, dan sebagainya (Amien, 2015, pp. 63-64). Maka memaknai perbedaan dengan pendekatan seperti di atas, peneliti rasa sudah kebablasan. Sikap toleran terhadap perbedaan jangan sampai menyentuh ranah yang lebih ekslusif, semisal akidah/keyakinan. Pendidikan multikultural yang mereka usung lebih berorientasi pada kebebasan HAM yang justru pada penempatannya tidak proporsional.

Dewasa ini kasus-kasus yang bermunculan di media massa, baik cetak, elektronik, maupun media online didominasi oleh berita-berita dengan muatan SARA. SARA merupakan akronim dari Suku, Agama dan Ras. Secara umum SARA merupakan berbagai pandangan dan tindakan yang didasarkan pada sentimen identitas yang menyangkut keturunan, agama, kebangsaan atau kesukuan dan golongan. Setiap tindakan yang melibatkan kekerasan, diskriminasi dan pelecehan yang didasarkan pada identitas diri dan golongan dapat dikatakan sebagai tindakan Sara.

Di Indonesia sendiri, isu SARA menjadi momok yang menakutkan bagi keberlangsungan hidup warga, betapa tidak, mayoritas kasus yang bermula dari Isu SARA bisa dipastikan chaos dan tak sedikit yang berujung kematian. Sebagai contoh kita mungkin masih ingat tragedi Trisakti 12 Mei 1998. Peristiwa ini bermula dari aksi unjuk rasa mahasiswa untuk menggulingkan pemerintahan Soeharto, yang berujung chaos dan menelan 4 korban mahasiswa yang tewas ditembak aparat. Influence aksi tersebut menyebar hampir ke penjuru Indonesia. Gelombang aksi di berbagai daerah bermunculan bak jamur di musim hujan.

Selanjutnya, mungkin masih ingat peristiwa kelam di tahun 1999 berkaitan dengan Isu SARA, yakni konflik agama yang meletup di AmbonLease. Aksi tersebut bermula dari konflik agama dan membesar menjadi konflik tatanan kehidupan. Aksi brutal terjadi dimana-mana dan banyak menelan korban. Kedua kubu berbeda agama ini saling serang dan bakar membakar bangunan serta sarana ibadah. Tahun 2001, lagi-lagi terjadi tragedi yang diakibatkan oleh isu SARA, yakni peristiwa yang disebut dengan tragedi Sampit. Tragedi ini melibatkan dua kelompok yang saling berebut pengaruh dan kekuasaan, yakni suku Dayak dan warga Madura. Konflik ini diduga 
dipicu oleh beberapa faktor diantaranya orang Dayak yang diduga tewas dibunuh oleh warga Madura hingga pemerkosaan gadis Dayak. Warga Madura sebagai pendatang di sana dianggap gagal beradaptasi dengan orang Dayak selaku tuan rumah. Akibat bentrok dua suku ini ratusan orang dikabarkan meninggal dunia. Bahkan banyak di antaranya mengalami pemenggalan kepala oleh suku Dayak yang kalap dengan ulah warga Madura saat itu. Pemenggalan kepala itu terpaksa dilakukan oleh suku Dayak demi memertahankan wilayah mereka yang waktu itu mulai dikuasai warga Madura.

Konflik selanjutnya yang berakar dari sentimen golongan terjadi di tahun 2012. Aksi penyerangan terhadap pengikut Syi'ah terjadi di Dusun Nangkernang, Desa Karang Gayam, Kecamatan Omben, Kabupaten Sampang, Madura, Jawa Timur pada Agustus 2012 silam. Sebanyak dua orang warga Syi'ah tewas dan enam orang lainnya mengalami luka berat serta puluhan warga mengalami luka ringan. Kasus ini sebenarnya sudah berlangsung sejak tahun 2004. Klimaksnya adalah aksi pembakaran rumah ketua Ikatan Jamaah Ahl al-Bait (IJABI), Tajul Muluk, beserta dua rumah jamaah Syi'ah lainnya serta sebuah mushala yang digunakan sebagai sarana peribadatan. Aksi tersebut dilakukan oleh sekira 500 orang yang mengklaim diri sebagai pengikut ahlus sunnah wal jama'ah.

Terakhir, isu Sara yang masih hangat di telinga kita adalah peristiwa di kepulauan seribu. Peristiwa yang terjadi di bulan september 2016 ini melibatkan Guberbur DKI Jakarta Basuki Tjahaya Purnama alias Ahok yang saat itu Ahok sedang melakukan kunjungan. Dalam sambutannya Ahok menyampaikan program kerjasama antara Pemerintah Provinsi DKI Jakarta dengan Sekolah Tinggi Perikanan (STP) Jakarta dalam bidang perikanan. Seperti yang dilansir media online Beritagar. id (Kamis, 6 Oktober 2016) dalam pidatonya, Ahok menjelaskan bahwa warga tak perlu takut soal kelanjutan program bantuan itu, bila dirinya tak terpilih dalam Pilgub DKI 2017. Lebih kurang, Ahok menjamin program itu akan tetap berjalan, apa pun hasil Pilgub kelak. "Jadi enggak usah pikiran. 'Akh! Nanti kalau enggak kepilih, pasti Ahok programnya bubar'. Enggak! Saya masih terpilih (menjabat) sampai Oktober 2017," kata Ahok. Setelahnya, terseliplah pernyataan dia soal penggunaan surat Al Maidah ayat 51 jelang Pilgub DKI 2017. "Jadi jangan percaya sama orang, kan bisa aja dalam hati kecil bapak ibu enggak pilih saya. Dibohongin pakai surat $\mathrm{Al}$ Maidah ayat 51, macam-macam itu. Itu hak bapak ibu.

Dari ungkapan itulah bola panas mulai bergulir, apalagi setelah video ungkapan ahok tersebut mulai tersebar di dunia maya. Sontak reaksi pun bermunculan di kalangan netizen yang mayoritas menyayangkan ungkapan tersebut. Bahkan media-media maistream Islam menjadikannya headline News 
dengan judul yang cenderung bernada peyoratif dan provokatif. Semisal yang terlihat dalam judul tulisan Islamedia. id: "Di hadapan Warga Kepulauan Seribu, Ahok Sebut Al-Qur'an Sebagai Kitab yang Membodohi Umat Islam”. Ada lagi judul tulisan yang memosisikan Ahok telah menyebut surat Al Maidah bohong belaka. Contohnya dalam judul VOA Islam, "Soal Pemimpin Kafir, Ahok Sebut Umat Islam Telah Dibohongi Surat Al Maidah Ayat 51”. Perkara makin ramai setelah munculnya petisi bertajuk "Ahok Jangan Lecehkan Ayat Al-Quran!” di Change. org. Kurang dari 24 jam, petisi yang digagas akun Irfan Noviandana itu sudah menuai lebih dari 31 ribu dukungan, Kamis malam (6/10/2016). Di linimasa Twitter keriuhan pun tercipta. Kata kunci "Basuki Tjahaja Purnama” dan "Al Maidah” ikut masuk Tren Twitter Indonesia, Kamis (6/10/2016).

Seperti yang sudah peneliti sampaikan di muka, bahwa isu SARA menjadi isu yang sangat sensitif bagi keberlangsungan hidup manusia. Beberapa peristiwa yang peneliti sampaikan bukan hanya sebatas menyampaikan data-data faktual yang terjadi, tetapi lebih kepada pentingnya penyadaran tentang keragaman kepentingan individu atau kelompok. Beragamnya kepentingan tersebut merupakan sebuah keniscayaan. Kepentingan tersebut dapat berupa kepentingan keyakinan, kepetingan adat, kepentingan politik, kepentingan budaya, dan kepentingan lainnya.

Secara geografis, Indonesia merupakan negara kepulauan yang terbentang dari Sabang sampai Merauke terdiri dari 35 provinsi. Tidak dapat dipungkiri Indonesia merupakan negara dengan tingkat keragaman yang sangat tinggi. Keragamannya tidak hanya sebatas pada teritorial antar pulau dan provinsi, tetapi sudah sampai pada satu wilayah. Keragamannya mulai dari agama, aliran kepercayaan, suku, budaya, etnis, dan lain sebagainya. Dalam hal agama, agama yang diakui di Indonesia berdasarkan UU No. 1/PNPS/1965 tentang Pencegahan Penyalahgunaan dan atau Penodaan Agama dalam penjelasannya disebutkan bahwa agama-agama yang dipeluk oleh penduduk di Indonesia ialah Islam, Kristen, Katolik, Hindu, Budha, dan Khong $\mathrm{Cu}$ (Confusius). Walaupun demikian, tentu saja tidak sertamerta menutup pintu keyakinan/kepercayaan lain bagi penduduk Indonesia. Bisa dikatakan Jumlah aliran kepercayaan di Indonesia lebih banyak ketimbang agama yang diakui di Indonesia itu sendiri mulai dari kepercayaan yang sifatnya tradisi/budaya, sampai pada aliran kepercayaan yang sifatnya mistis. Ditinjau dari aspek agama dan aliran kepercayaan saja kita bisa bayangkan bagaimana rentannya konflik kepentingan diantara penduduk Indonesia, belum lagi keragaman dalam bentuk yang lain semisal tradisi, adat, budaya dan politik.

Seperti yang sudah peneliti utarakan, bahwa penduduk Indonesia menyadari suatu keanekaragaman yang sifatnya regional. Sebagai contoh, 
wilayah Jawa terbagi menjadi 3 provinsi, Jawa Barat, Jawa Tengah, dan Jawa Timur. Walaupun ketiganya berada dalam daratan pulau yang sama, adat istiadat, bahasa, budaya dan corak kehidupan diantara ketiganya memiliki perbedaan yang cukup signifikan. Seperti yang dikatakan Koentjaraningrat paling tidak menurut pandangan orang Jawa sendiri, kebudayaannya tidak merupakan suatu kesatuan yang homogen. Mereka sadar akan adanya suatu keanekaragaman yang sifatnya regional. Kebudayaan Jawa yang hidup di kotakota Yogya dan Solo merupakan peradaban orang Jawa yang berakar dari kraton. Peradaban ini mempunyai suatu sejarah kesusasteraan yang telah ada sejak empat abad yang lalu, dan memiliki kesenian yang maju berupa taritarian dan seni suatu kraton serta yang ditandai oleh suatu kehidupan keagamaan yang sangat sinkretistik, campuran dari agama Hindu, Buddha, dan Islam (Koentjaraningrat, 2001, p. 25).

Keragaman yang lain tampak dari norma dan etika. Norma merupakan sumber hukum yang memiliki peranan penting dalam menjaga kondusivitas dan stabilitas tatanan kehidupan masyarakat Indonesia. Norma yang kemudian terejawantahkan menjadi sebuah etika dan moral pada hakikatnya berdiri di atas semua kepentingan. Tetapi dalam entitas tertentu norma atau etika bisa menjadi identitas teritorial tertentu dan mewakili kepentingan tertentu. Norma Inilai akan suatu hal tiap daerah bisa berbeda satu sama lain. Misalnya, dalam kehidupan keluarga Jawa tidak terdapat kesamaan kedudukan antara suami dan istri. Suami memiliki kedudukan yang lebih tinggi dan penting serta mempunyai kekuasaan yang lebih besar (Astiyanto, 2012, p. 3), padahal kita berpendapat bahwa istri di sebagian daerah perkotaan mempunyai peranan yang penting, bahkan dalam hal-hal tertentu perannya lebih besar ketimbang suami. Meskipun demikian hubungan suami dan istri dalam kebudayaan Jawa mengenal tata krama dengan falsafah sing bekti marang laki. Dinamakan bekti jika istri dapat melakukan tugasnya yang baik sebagai istri dalam hal melayani dan menyiapkan kebutuhan suami (Astiyanto, 2012, p. 4).

Sampai sana peneliti bisa simpulkan bahwa Indonesia merupakan negara multikultural dengan kompleksitas permasalahan yang rumit. Benang merah dari sesuatu yang rumit tersebut bisa dikatakan buah dari kesalahpahaman dan perbedaan persepsi, juga perbedaan sikap tentang "perbedaan" itu sendiri. Sehingga munculah letupan-letupan konflik kepentingan diantara entitas yang berbeda-beda tersebut. Kalau peneliti meminjam istilah Koentjaraningrat, masyarakat kita mengalami kesalahpahaman mengenai konsep Ras. Menurut beliau makhluk manusia yang hidup dalam lingkungan alam yang beranekaragam di seluruh muka bumi ini dapat digolongkan berdasarkan ciriciri fisik mereka yang tampak nyata, seperti warna kulit, warna dan bentuk rambut, bentuk bagian-bagian muka, dan sebagainya, sehingga timbul 
pengertian "ras" atau golongan manusia secara umum memiliki ciri-ciri tubuh tertentu. Dalam sejarah bangsa-bangsa, konsepsi mengenai keanekaragaman ciri tubuh itu telah mengakibatkan derita dan malapetaka yang berkepanjangan karena adanya salah paham dalam pandangan berbagai bangsa di dunia. Karena adanya salah paham itu, ciri-ciri ras yang seharusnya hanya menyangkut ciriciri jasmani belaka telah disalahartikan dengan ciri-ciri rohani, dan lebih-lebih karena terjadi penilaian tinggi-rendah tingkat kerohanian terhadap berbagai ras yang ada (Koentjaraningrat, 2001, p. 64), Begitu juga dengan ciri-ciri dan identitas kebudayaan/tradisi dan keyakinan antar individu, kelompok atau golongan mereka letakan dalam posisi sebagai jurang pembeda yang sangat terjal. Belum lagi klaim kebenaran kelompok menjadikan Indonesia rentan konflik kepentingan atas Isu SARA.

Berbicara mengenai kepentingan khalayak, Islam sebagaimana dikatakan Daud Ali adalah agama wahyu terakhir yang merupakan satu sistem aqidah, syari'ah, dan akhlak yang mengatur segala tingkah laku manusia dalam berbagai hubungan, baik hubungan manusia dengan Tuhannya maupun hubungan manusia dengan dirinya sendiri, masyarakat, alam atau makhluk lainnya. Artinya agama Islam membawa penganutnya pada area teknis yang menyangkut dengan hajat hidup orang banyak. Islam memberikan implikasi positif bagi penganutnya bagaimana cara dia bergaul, bagaimana dia menyikapi perbedaan dan bagaimana menempatkan perbedaan dalam porsi yang semestinya. Para nabi dan rasul pun diutus (ditempatkan) pada satu kondisi yang bertentangan dengan ruh syari'at yang akan disampaikannya. Mereka mempunyai tugas memberikan pemahaman, menyampaikan risalah dakwah di tengah perbedaan. Mereka berdakwah dengan porsi yang benar, mereka tetap santun tanpa mengurangi substansi dari dakwah tersebut. Mereka tetap kerja keras menyampaikan dakwah Islam tanpa khawatir kecaman dan siksaan di pihak lain. Karena pada hakikat yang benar sudah jelas, yang salah pun sudah jelas (Ali, 1989, p. 3).

Berbicara mengenai ketegasan dalam berdakwah dewasa ini, peneliti banyak menemukan ambiguitas terutama dari para intelektual muslim. Mereka punya pemahaman yang lurus tentang hakikat kebenaran, tetapi tumpul disampaikan tatkala berbenturan dengan perbedaan atau kepentingan kelompok. Gejala ini menyerang di sebagian intelektual muslim karena "virus" yang dinamakan dengan SEPILIS (Sekularisme, Pluralisme, dan Liberalisme). Virus yang menyerang hampir di setiap agama termasuk Islam.

Maka memaknai perbedaan dengan pendekatan seperti di atas, peneliti rasa sudah kebablasan. Sikap toleran terhadap perbedaan jangan sampai menyentuh ranah yang lebih ekslusif, semisal akidah/keyakinan. Pendidikan multikultural yang mereka usung lebih berorientasi pada kebebasan HAM yang 
justru pada penempatannya tidak proporsional. Misalkan dalam kasus Ahok yang dipelintir menjadi kasus SARA atas dasar sentimen etnis, sehingga yang menuntut Ahok untuk dihukum dikatakan tidak multi etnis atau multikultural. Padahal apa yang dilakukan oleh Ahok sudah masuk dalam ranah yang lebih eksklusif, menyangkut ranah akidah atau keyakinan dalam hal ini keyakinan umat Islam. Begitu pula dengan kasus-kasus penistaan agama yang dilakukan oleh kelompok minoritas selalu saja luput dari liputan media, berbeda halnya dengan apa yang dilakukan oleh kelompok mayoritas. Islam sendiri mengusung keadilan dalam porsi yang tepat sebagaimana Allah jelaskan dalam QS Al-Maidah ayat 8 bahwa "Janganlah sekali-kali kebencianmu terhadap suatu kaum, mendorong kamu untuk berlaku tidak adil. Berlaku adillah karena adil itu lebih dekat kepada takwa. "Ibnu Jarir dalam tafsir atThabari menyebutkan bahwa ayat ini diturunkan berkenaan dengan kedatangan Rasulullah kepada orang Yahudi untuk meminta bantuan dalam urusan diyat (denda). Kemudian mereka (orang Yahudi) bermaksud untuk membunuh Nabi, maka turunlah ayat ini. Di sinilah makna keadilan dalam Islam terlihat jelas, Allah mengarahkan manusia agar menjaga diri dan berlaku adil, karena ia lebih dekat pada ketakwaan (Ali M. S., 2008, p. 33).

Pendidikan multikultural adalah proses pengembangan seluruh potensi manusia yang menghargai pluralitas dan heterogenitasnya sebagai konsekuensi keragaman budaya, etnis, suku, dan aliran (agama). Pendidikan multikultural menekankan sebuah filosofi pluralisme budaya ke dalam sistem pendidikan yang didasarkan pada prinsip-prinsip persamaan (equality), saling menghormati dan menerima serta memahami dan adanya komitmen moral untuk sebuah keadilan sosial. Pendidikan multikultural berawal dari berkembangnya gagasan dan kesadaran tentang interkulturalisme seusai Perang Dunia II. Kemunculan gagasan dan kesadaran interkulturalisme ini selain terkait dengan perkembangan politik internasional menyangkut HAM, kemerdekaan dari kolonialisme, diskriminasi rasial, dan lain-lain, juga karena meningkatnya pluralitas di negara-negara Barat sendiri sebagai akibat dari peningkatan migrasi dari negara-negara baru merdeka ke Amerika dan Eropa (Ibrahim, 2013, p. 129).

James Banks menyatakan bahwa pengertian pendidikan multikultural sebagai pendidikan untuk people of color (Ibrahim, 2013, p. 135). Menurut Banks pendidikan Multikultural merupakan suatu rangkaian kepercayaan (Set of beliefs) dan penjelasan yang mengakui dan menilai pentingnya keragaman budaya dan etnis dalam bentuk gaya hidup, pengalaman sosial, identitas pribadi, kesempatan pendidikan dari individu, kelompok, ataupun negara (Suryana \& Rusdiana, 2015, p. 196). Ia mendefinisikan pendidikan multikultural adalah ide, gerakan, pembaharuan pendidikan, dan proses 
pendidikan yang tujuan utamanya adalah untuk mengubah struktur lembaga pendidikan agar siswa laki-laki dan perempuan, siswa berkebutuhan khusus, dan siswa yang merupakan anggota dari kelompok ras, etnis, dan kultur yang bermacam-macam memiliki kesempatan yang sama untuk mencapai prestasi akademis di sekolah (Suryana \& Rusdiana, 2015, p. 96). Pengertian ini senada dengan pengertian yang dikemukakan oleh Sleeter bahwa pendidikan multikultural adalah sekumpulan proses yang dilakukan oleh sekolah untuk menentang kelompok yang menindas. Pengertian-pengertian ini tidak sesuai dengan konteks pendidikan di Indonesia karena Indonesia memiliki konteks budaya yang berbeda dari Amerika Serikat walaupun keduanya memiliki bangsa dengan multi-kebudayaan.

Pendidikan multikultural sebenarnya merupakan sikap "peduli" dan mau mengerti (difference) atau "politics of recognition" politik pengakuan terhadap orang-orang dari kelompok minoritas. Pendidikan multikultural melihat masyarakat secara lebih luas. Berdasarkan pandangan dasar bahwa sikap "indiference" dan "non-recognition" tidak hanya berakar dari ketimpangan struktur rasial, tetapi paradigma pendidikan multikultural mencakup subjeksubjek mengenai ketidakadilan, kemiskinan, penindasan, dan keterbelakangan kelompok-kelompok minoritas dalam berbagai bidang: sosial, budaya, ekonomi, pendidikan, dan lain sebagainya. Tujuan pendidikan Islam bukan sebatas mengisi pikiran siswa dengan ilmu pengetahuan dan materi pelajaran, akan tetapi membersihkan jiwanya yang harus diisi dengan akhlak dan nilainilai yang baik dan dikondisikan supaya biasa menjalani hidup dengan baik. Hal tersebut sesuai dengan tujuan pendidikan multikultural, yaitu untuk menciptakan kehidupan yang harmonis dalam masyarakat yang serba majemuk (Ibrahim, 2013, p. 129).

Pendidikan multikultural berasal dari dua kata pendidikan dan multikultural. Pendidikan merupakan proses pengembangan sikap dan tata laku seseorang atau sekelompok orang dalam usaha mendewasakan manusia melalui pengajaran, pelatihan, proses, perbuatan dan cara-cara yang mendidik. Di sisi lain Pendidikan adalah Transfer of knowledge atau memindah ilmu pengetahuan. Sedangkan Multikultural secara etimologis multi berarti banyak, beragam dan aneka sedangkan kultural berasal dari kata cultureyang mempunyai makna budaya, tradisi, kesopanan atau pemeliharaan. Rangkaian kata pendidikan dan multikultural memberikan arti secara terminologis adalah proses pengembangan seluruh potensi manusia yang menghargai pluralitas dan heterogenitasnya sebagai konsekuensi keragaman budaya, etnis, suku dan aliran (agama). Berikut beberapa pendapat para pakar pendidikan mengenai Pendidikan Multikultural sebagaimana dikutip oleh Rustam Ibrahim Pertama, Zakiyuddin Baidhawi mendefinisikan pendidikan multikultural adalah suatu 
cara untuk mengajarkan keragaman (teaching diversity). Kedua, M. Ainul Yaqin memahami pendidikan multikultural sebagai strategi pendidikan yang diaplikasikan pada semua jenis mata pelajaran dengan cara menggunakan perbedaan-perbedaan kultural yang ada pada para siswa seperti perbedaan etnis, agama, bahasa, gender, klas sosial, ras, kemampuan dan umur agar proses belajar menjadi mudah. Ketiga, John W. Santrock mendefinisikan pendidikan multikultural adalah pendidikan yang menghargai diversitas dan mewadahi perspektif dari beragam kelompok kultural atas dasar basis regular (Ibrahim, 2013, pp. 136-137).

Pengertian Islamic worldview menurut Atif al-Zayn adalah adalah almabda' al-Islami, yaitu aqîdah fikriyah (kepercayaan yang rasional) yang berdasarkan pada akal, sebab setiap muslim wajib beriman kepada hakikat wujud Allah SWT, kenabian Muhammad SAW, dan kepada al-Qur'an dengan akal. Iman kepada hal-hal yang gaib berdasarkan dengan carapenginderaan yang diteguhkan oleh akal sehingga tidak dapat dipungkiri lagi. Iman kepada Islam sebagai dien yang diturunkan melalui Nabi Muhammad SAW untuk mengatur hubungan manusia dengan Tuhan, dengan dirinya dan lainnya.

Menurut Sayyid Qutb istilah yang tepat untuk Islamic worldview adalah al-Tasawwur al-Islami, yaitu akumulasi dari keyakinan asasi yang terbentuk dalam pikiran dan hati setiap muslim yang memberi gambaran khusus tentang wujud dan apa-apa yang terdapat di balik itu. Menurut Syed Muhammad Naquib al-Attas, Islamic worldview adalah visi tentang realitas dan kebenaran, yang terbaca oleh mata hati kita dan yang menerangkan tentang hakikat wujud yang sesungguhnya, sebab totalitas dunia wujud itulah yang diproyeksikan Islam. Oleh sebab itu, istilah worldview ini diterjemahkan oleh al-Attas ke dalam terminologi Islam (bahasa Arab) sebagai Ru'yat al-Islam li al-Wujud yang berarti pandangan Islam terhadap hakikat dan kebenaran tentang alam semesta. Menurut al-Maududi istilah untuk Islamic worldview adalah IslamiNazariyât, yaitu pandangan hidup yang dimulai dari konsep keEsaan Tuhan (syahadad) yang berimplikasi pada keseluruhan kegiatan manusia di dunia. Sebab shahadad adalah pernyataan moral yang mendorong manusia untuk melaksanakannya dalam kehidupan secara menyeluruh.

Pengertian Islamic worldview menurut Atif al-Zayn adalah adalahalMabda' al-Islâmî, yaitu aqidah fikrîyah(kepercayaan yang rasional) yang berdasarkan pada akal, sebab setiap Muslim wajib beriman kepada hakikat wujud Allah, kenabian Muhammad, dan kepada al-Qur'ân dengan akal. Iman kepada hal-hal yang gaib berdasarkan dengan cara penginderaan yang diteguhkan oleh akal sehingga tidak dapat dipungkiri lagi. Iman kepada Islam sebagai dîn yang diturunkan melalui Nabi Muhammad untuk mengatur hubungan manusia dengan Tuhan, dengan dirinya dan lainnya. 
Menurut Syed Muhammad Naquib al-Attas, Islamic worldview adalah visi tentang realitas dan kebenaran, yang terbaca oleh mata hati kita dan yang menerangkan tentang hakikat wujûd yang sesungguhnya, sebab totalitas dunia wujûd itulah yang diproyeksikan Islam. Oleh sebab itu, istilah worldview ini diterjemahkan oleh al-Attas ke dalam terminologi Islam (bahasa Arab) sebagai Ru'yat al-Islâm li al-Wujûd yang berarti pandangan Islam terhadap hakikat dan kebenaran tentang alam semesta. Masih menurut Al-Attas (dalam Mohamed Haneef, 1997: 41) bahwa:

The relationship between din, the Islamic worldview, and its implications on ethics and morality. He stresses the importance of language in elaborating the meaning of fundamental termsand concepts which represent the worldview of a people.

Menurut al-Maududi istilah untuk Islamic worldview adalah IslamiNazariyat yaitu pandangan hidup yang dimulai dari konsep ke-Esaan Tuhan (syahadad) yang berimplikasi pada keseluruhan kegiatan manusia di dunia. Sebab shahadad adalah pernyataan moral yang mendorong manusia untuk melaksanakannya dalam kehidupan secara menyeluruh.

Definisi para ulama tersebut di atas secara umum hampir sama, tapi jika dicermati lebih detail dan dihubungkan dengan gerakan yang mereka lakukan hanya menunjukkan perbedaan penekanan pada tingkat aksi. Definisi alMaududi lebih berorientasi pada struktur kekuasaan politik yang membuka ruang bagi pelaksanaan hukum Tuhan, definisi Shyakh Atif al-Zayn menunjukkan kelengkapan konsep yang diorientasikan pada pelaksanaan ibadah yang luas, Sayyid Qutb menekankan pada pandangan ideologis, sedangkan Syed Muhammad Naquib al-Attas lebih menekankan pada aspek epistemologisnya, yaitu penekanan pada aspek visi tentang realitas dan kebenaran.

\section{Metode}

Penelitian ini menggunakan pendekatan kualitatif dengan metode library research (studi pustaka), adapun teknik analisis data yang digunakan adalah content analisis atau analisis isi. Analisa data dapat juga dilakukan melalui tahapan display data, reduksi data, verifikasi data dan kesimpulan

\section{Hasil Penelitian dan Pembahasan}

Salah satu wacana fenomenal terkait dengan pendidikan Multikultural yang dikaitkan dengan Islamic Worldview adalah Islamisasi Ilmu Pengetahuan. Secara historis, ide atau gagasan Islamisasi Ilmu pengetahuan muncul pada saat diselenggarakan Konferensi Dunia Pertama tentang Pendidikan Islam di 
Mekah pada tahun 1977. Konferensi yang diprakarsai oleh King Abdul Aziz University ini berhasil membahas 150 makalah yang ditulis oleh sarjana-sarjana dari 40 negara, dan merumuskan rekomendasi untuk pembenahan serta penyempurnaan sistem pendidikan Islam yang diselenggarakan oleh umat Islam seluruh dunia. Salah satu gagasan yang direkomendasikan adalah menyangkut Islamisasi Ilmu pengetahuan. Gagasan ini antara lain dilontarkan oleh Syed Muhammad Naquib al-Attas dalam makalahnya yang berjudul "Preliminary Thoughts on the Nature of Knowledge and the Definition and the Aims of Education dan Ismail R. al-Faruqi dalam makalahnya "Islamicizing Social Science. " (Thoib \& Mukhlis, 2013, p. 67).

Secara substansial proses Islamisasi Ilmu telah terjadi sejak masa Rasulullah. Hal ini dapat kita lihat dari proses pengislaman yang dilakukan oleh Nabi Muhammad Saw. terhadap masyarakat Arab pada saat itu. Melalui ajaran-ajaran al-Qur'an, sebagai sumber hukum Islam pertama, beliau merubah seluruh tatanan Arab Jahiliyah kepada tatanan masyarakat Islam hanya dalam kurun waktu dua puluh tiga tahun. Dengan al-Qur'an, Muhammad Saw. merubah pandangan hidup mereka tentang manusia, alam semesta, dan kehidupan dunia. Pengislaman ilmu ini diteruskan oleh para sahabat, tabiin dan ulama-ulama sehingga umat Islam mencapai kegemilangan dalam ilmu. Dengan pengetahuan Islam yang mendalam, mereka menyaring filsafat Yunani Kuno untuk disesuaikan dengan pemikiran Islam. Sebagai hasilnya, ada hal-hal dari filsafat Yunani Kuno yang diterima dan ada juga yang ditolak. " (Thoib \& Mukhlis, 2013, p. 68).

Oleh karena itu, Islamisasi dalam arti kata yang sebenarnya bukanlah perkara baru bila ditinjau dari aspek yang luas ini. Hanya saja, secara operasional, istilah Islamisasi Ilmu baru dipopulerkan sebagai kerangka epistemologi baru oleh para pembaru Muslim pada tahun 70-an. Gagasan Islamisasi Ilmu di kalangan pemikir Muslim merupakan program epistemologi dalam rangka membangun (kembali) peradaban Islam. Hal ini disebabkan adanya perbedaan yang fundamental antara pandangan keilmuan dalam Islam dengan peradaban Barat pada tataran ontologi dan epistemologi (Thoib \& Mukhlis, 2013, pp. 69-70).

Para cendekiawan yang terlibat dalam proyek Islamisasi Ilmu seperti Syed Muhammad Naquib al-Attas, selanjutnya disebut al-Attas, menyadari bahwa virus yang terkandung dalam Ilmu Pengetahuan Barat modern-sekuler merupakan tantangan yang paling besar bagi kaum Muslimin saat ini. Dalam pandangannya, peradaban Barat modern telah membuat ilmu menjadi problematis. Selain telah salah memahami makna ilmu, peradaban Barat juga telah menghilangkan maksud dan tujuan ilmu. Sekalipun peradaban Barat modern juga menghasilkan ilmu yang bermanfaat, namun peradaban tersebut 
juga telah menyebabkan kerusakan dalam kehidupan manusia. Dalam pandangan al-Attas, Westernisasi ilmu adalah hasil dari kebingungan dan skeptisisme. Westernisasi ilmu telah mengangkat keraguan dan dugaan ke tahap metodologi ilmiah. Bukan hanya itu, Westernisasi ilmu juga telah menjadikan keraguan sebagai alat epistemologi yang sah dalam keilmuan. Menurutnya lagi, Westernisasi ilmu tidak dibangun di atas wahyu dan kepercayaan agama, namun dibangun di atas tradisi budaya yang diperkuat dengan spekulasi filosofis yang terkait dengan kehidupan sekular yang memusatkan manusia sebagai makhluk rasional. Akibatnya, ilmu pengetahuan dan nilai-nilai etika dan moral yang diatur oleh rasio manusia terus menerus berubah. Al-Attas bercita-cita ingin menjadikan peradaban Islam kembali hidup dan memiliki pengaruh yang mewarnai peradaban global umat manusia. Karena itu, seluruh hidupnya ia persembahkan bagi upaya-upaya revitalisasi peradaban Islam, agar nilai-nilai yang di masa lalu dapat membumi dan menjadi ikon kebanggaan umat Islam, dapat menjelma dalam setiap lini kehidupan kaum Muslim sekarang ini (Thoib \& Mukhlis, 2013, pp. 72-73).

Menurut al-Attas, ilmu pengetahuan tidak bersifat netral dan bebas nilai. Sehingga ketika ilmu berkembang di sebuah wilayah, ilmu tersebut dibentuk berdasarkan nilai-nilai budaya, ideologi, dan agama yang dianut oleh para pemikir dan ilmuan di wilayah tersebut. Kemudian terjadilah apa yang disebut dengan Helenisasi Ilmu, Kristenisasi Ilmu, Islamisasi Ilmu pada masa klasik Islam, kemudian Westernisasi ilmu dalam bentuk sekularisasi oleh masyarakat barat terhadap Ilmu (Thoib \& Mukhlis, 2013, p. 73).

Oleh karena itu, proses "Islamisasi" oleh Mulyadhi Kartanegara adalah suatu bentuk "naturalisasi" ilmu dalam rangka meminimalisir dampak negatif sains sekuler terhadap kepercayaan agama (Thoib \& Mukhlis, 2013, pp. 7374), Menurut al-Attas ada lima faktor yang menjiwai budaya dan peradaban barat: (1) akal yang diandalkan untuk membimbing kehidupan manusia, (2) bersikap dualistik terhadap realitas dan kebenaran, (3) menegaskan aspek eksistensi yang memproyeksikan pandangan hidup sekuler, (4) membela doktrin humanisme, (5) menjadikan drama dan tragedi sebagai unsur-unsur yang dominan dalam fitrah kemanusiaan (Thoib \& Mukhlis, 2013, p. 74).

Kelima unsur tersebut di atas, menurut al-Attas, harus diisolir dari setiap bidang ilmu pengetahuan modern saat ini, khususnya dalam ilmu pengetahuan humaniora. Sedangkan dalam ilmu-ilmu alam, fisika dan aplikasinya harus diislamkan juga, khususnya dalam penafsiran-penafsiran akan fakta-fakta dan dalam formulasi teori-teori. Setelah unsur-unsur patogen (asing) bagi doktrin Islam tersebut diisolir, al-Attas kemudian menyarankan agar unsur dan konsep utama Islam yang terdiri dari konsep: manusia, dìn, 'ilmdan ma'rifah, hikmah, 'adl, 'amal-adab, dan konsep universalitas (kulliyah-jam'iyyah) diserapkan ke 
dalam konsep ilmu pengetahuan kontemporer. Kesemua unsur tersebut ditambatkan pada konsep tauhid, syari'ah, sunnah, dan tarikh (Thoib \& Mukhlis, 2013, p. 74).

Kelima hal di atas, merupakan prinsip-prinsip utama dalam pengembangan keilmuan di Barat, yang dinilai bertentangan dengan nilai-nilai Islam. Supaya umat Islam terhindar dari prinsip-prinsip yang menjebak di atas, maka ada empat poin yang harus diperhatikan seorang Muslim dalam mengembangkan ilmu pengetahuan, yaitu: (1) prinsip-prinsip utama Islam sebagai intisari peradaban Islam, (2) pencapain sejarah kebudayaan Islam sebagai manifestasi ruang dan waktu dari prinsip-prinsip utama Islam, (3) bagaimana kebudayaan Islam dibandingkan dan dibedakan dengan kebudayaan lain dari sudut manifestasi dan intisari, (4) bagaimana kebudayaan Islam menjadi pilihan yang paling bermanfaat berkaitan dengan masalah-masalah pokok Islam dan non Islam di dunia saat ini (Thoib \& Mukhlis, 2013, p. 75).

Orientasi pendidikan multikutural sendiri adalah "memanusiakan kemanusiaan manusia". Kemanusiaan manusia pada dasarnya adalah pengakuan atas pluralitas, heterogenitas, dan keragaman manusia itu sendiri. pendidikan multikultural tidak mentolelir adanya ketimpangan kurikulum. Artinya, pendidikan multikultural menghargai adanya perbedaan filosofi keilmuan. Ilmu-ilmu yang berbeda bukan untuk dikonfrontasikan apalagi saling menjegal dan merasa paling benar, melainkan saling melengkapi dan menunjang. Sifat holistik ajaran Islam memiliki implikasi praktis terhadap tujuan, kurikulum, metode dan sistem evaluasi dalam pendidikan Islam. Dengan sifat holistik ini, tujuan pendidikan meliputi kepentingan hubungan dengan manusia, alam, dan Tuhan sekaligus

Menurut Muhammad Zuhdi, salah satu persoalan penting sekarang adalah isu mengenai pendidikan agama didalam kelas, Pengenalan berbagai macam agama didalam kelas telah menjadi bagian dari kurikulum sekolah sejak lama. Sayangnya perbedaan ini disajikan hanya sebagai budaya bukan sebagai keyakinan. Hal ini menimbulkan kesulitan bagi siswa untuk memahami dan menghormati keyakinan agama lain.

Ajaran Islam yang sangat mulia terkait dengan multikulturalisme adalah persaudaraan (al-ukhuwah). Menurut MunzirSuparta, Seiring berjalan waktu konsep persaudaraan (brotherhood) yang digulirkan Rasulullah mengalami distorsi makna yang mendalam. Persaudaraan hanya diartikan hanya dengan menjalin persaudaraan sesama Islam, non-Islam dianggap diluar relasi persaudaraaan. Bahkan lebih ekstrim lagi persaudaraan hanya untuk orang yang se-aliran dan se-paham. Secara umum sebaran materi tentang persaudaraan/nilai kemanusiaan dalam buku teks pendidikan agama Islam seperti yang termuat dalam Standar Kompetensi dan Kompetensi Dasar 
Pendidikan Agama Islam pada Sekolah Menengah Atas (SMA) dapat dilihat dalam pokok bahasan yang disajikan. Husnuzhan terhadap sesama manusia suatu isu multikulturalisme yang menyangkut nilai dasar manusia dalam menjalin persaudaraan dan pergaulan antara sesama umat beragama, hal tersebut juga termasuk dalam sejarah dakwah Rasulullah dalam periode Mekah, baik secara substansi maupun strateginya.

Keberagaman dan pluralisme di negeri ini merupakan realitas empirik yang tidak terbantahkan. Oleh sebab itu, keberagaman harus dipandang sebagai sebuah rahmat dan potensi positif untuk mengembangkan bangsa dan negara, dan bukan sebaliknya. Dalam buku teks Pendidikan Agama Islam din Sekolah Menengah Atas (SMA) sebaran materi tentang pluralisme ini dapat dilihat dalam pokok bahasan mengenai Kebebasan beragama dalam Al-Qur'an Surah Al-Kahfi, 18: 29, dalam hal ini pembahasannya diangkat juga tentang tidak adanya toleransi dalam hal keimanan dan peribahan yang tercermin juga dalam Al-Qur'an Surah Al-Kafirun, 109: 1-6. Dengan demikian, sangat jelas bahwa ketunggalan dalam beragama dan berkeyakinan tidaklah dikehendaki Tuhan. Pada ayat lain yang sangat populer antara lain disebutkan "Tidak ada paksaan dalam memasuki agama". Berdasarkan ayat tersebut dapat dipahami bahwa disamping tidak boleh ada paksaan bagi seseorang untuk memeluk suatu agama atau pindah agama, orang juga dibebaskan apabila memilih tidak beragama. Karena jalan yang benar dan jalan yang salah sudah dibentangkan Tuhan. Terserah kepada setiap orang untuk memilih antara dua jalan tersebut, tentu dengan segala konsekuensinya.

Dalam menanggapi keberbedaan dan keragaman budaya, suku, bangsa, bahasa, agama dan sebagainya. Islam menawarkan sebuah konsepsi berupa toleransi. Konsep ta'aruf harus direalisasikan dalam kehidupan nyata. Salah satunya dengan mengembangkan sikap toleransi antar sesama, saling menghargai dan menghormati. Tema tentang toleransi terdapat juga dalam pokok bahasan mengenai Kebebasan beragama dalam Al-Qur'an Surah AlKahfi, 18: 29, tentang tidak adanya toleransi dalam hal keimanan dan peribadahan, dalam Surah Al-Kafirun, 109:1-6, dan tentang sikap terhadap orang yang berbeda pendapat dalam Al-Qur'an Surah Yunus: 10:40-41. Ada beberapa ayat Al-Qur'an yang bisa ditunjuk sebagai bukti pengakuan terhadap agama-agama lain. Seperti pengakuan terhadap eksistensi dan kebenaran kitabkitab sebelum Islam. Taurat dan Injil misalnya. Ini dapat dilihat pada Qur'an Surah al-Mâidah (5): 44. Pembahasan tentang ini dalam Materi PAI di SMA dapat dilihat dalam pokok bahasan tentang Iman Kepada Kitab-kitab Allah.

Perspektif teologi Islam tentang kerukunan hidup antar agama dan konsekuensinya, antar umat beragama berkaitan erat dengan doktrin Islam tentang hubungan antara sesama manusia dan hubungan antara Islam dengan 
agama lain, Islam mengakui hak hidup agama-agama lain, dan membenarkan para pemeluk agama lain tersebut untuk menjalankan ajaran-ajaran agama masing-masing. Disinilah letak dasar ajaran Islam mengenai toleransi beragama. Salah satu keunikan dalam Islam adalah menjadikan kepercayaan pada kebenaran agama lain sebagai syarat yang perlu bagi keimanan agamanya sendiri. Menurut Glasse, kenyataan bahwa sebuah wahyu (Islam) menyebut (wahyu-wahyu) lain sebagai absah merupakan peristiwa luar biasa dalamdalam sejarah agama-agama.

Sejarah perkembangan ilmu fiqih sebagai jalan keluar dari permasalahan yang berkembang di kalangan umat dari zaman ke zaman yang senantiasa meminta etika dan paradigma baru, sejauh yang kita amatifiqih klasik cenderung mengedepankansudut pandang antagonistik bahkan penolakan terhadap komunitas agama lain. Banyak konsep fiqih menempatkan penganut agama lain lebih rendah ketimbang umat Islam, hingga berimplikasi mendiskreditkan. Sejumlah kitab fiqih yang diajarkan baik dipesantren maupun sekolah keagamaan, pada umumnya hanya membacakan kembali kitab-kitab fiqih yang ditulis para ulama beberapa abad yang silam. Mereka hanya mereproduksi pandangan-pandangan fiqih klasik, dan tidak memproduksi pandangan alternatif yang relevan dengan kontekkekinian. Dalam buku teks PAI terlalu minim sekali perdebatan ulama atau Imam Mujtahid (terutama Imam empat Mazhab seperti Hanafi, Maliki, Syafíi dan Hambali).

Penerapan pendidikan yang multikultural sesungguhnya dapat dijumpai contohnya pada apa yang dilakukan Nabi Muhammad saw sewaktu tampil sebagai pemimpin agama dan pemimpin negara di Madinah. Sejarah mencatat, bahwa masyarakat madinah adalah masyarakat yang memiliki latar belakang agama, suku, budaya, dan sebagainya yang amat heterogen dan relevan untuk dijadikan sebagai contoh pelaksanaan konsep masyarakat madani serta penerapan asas pendidikan multikultural. Pendidikan multikultural pada masa kejayaan Islam, ketika al-Ma'mûn menjadi khalifah (813-833 M) dari bani Abbas di Bayt al-Hikmah, Bayt al-Hikmah sendiri merupakan institusi pendidikan tinggi Islam pertama yang dibangun pada tahun $830 \mathrm{M}$ oleh khalifah al-Ma'mûn. Institusi ini telah menjadikan peradaban baru dimana bangsa Barat belum mengenal apa yang disebut konsep pendidikan multikultural dalam pendidikan. Konsep demokrasi dan pluralitas begitu nyata dalam kehidupan sehari-hari termasuk dalam kegiatan pendidikan. 


\section{Kesimpulan}

Pendidikan multikultural menekankan sebuah filosofi pluralisme budaya ke dalam sistem pendidikan yang didasarkan pada prinsip-prinsip persamaan (equality), saling menghormati dan menerima serta memahami dan adanya komitmen moral untuk sebuah keadilan sosial. Diharapkan setelah muatan pendidikan multikultural diajarkan kepada objek pendidikan, maka sikap "peduli" dan mau mengerti (difference) atau "politics of recognition" politik pengakuan terhadap orang-orang dari kelompok minoritas tumbuh dalam benak objek pendidikan. Dikarenakan pendidikan multikultural melihat masyarakat secara lebih luas. Berdasarkan pandangan dasar bahwa sikap "indiference" dan "non-recognition" tidak hanya berakar dari ketimpangan struktur rasial, tetapi paradigma pendidikan multikultural mencakup subjeksubjek mengenai ketidakadilan, kemiskinan, penindasan, dan keterbelakangan kelompok-kelompok minoritas dalam berbagai bidang: sosial, budaya, ekonomi, pendidikan, dan lain sebagainya.

Dalam perspektif Islamic Worldview, sebagaimana dijelaskan dalam AlQur'an, sudah menjadi fitrah (bawaan) atau tabî'at al-kaun manusia diciptakan oleh Allah berbeda. Namun dalam pandangan Islam, perbedaan tersebut lantas tidak menjadi tolak ukur kemuliaan seseorang, Dalam perspektif Islamic Worldview, perbedaan yang merupakan sebuah keniscayaan bukanlah merupakan hal yang substantif. Justru dari perbedaan tersebut manusia diharapkan saling mengenal satu sama lain, dan tidak menjadi standar kemuliaan, yang menjadi standar kemuliaan dalam agama Islam adalah ketakwaannya.

\section{DAFTAR PUSTAKA}

Ali, D. (1989). Islam untuk Disiplin Ilmu Hukum Sosial Politik. Jakarta: Bulan Bintang.

Ali, M. S. (2008). Jangan Mudah Memvonis Salah, Terj. Amar Syarifudin. Solo: Media Islamika.

Amien, S. (2015). Risalah Dakwah Ustadz Shiddiq Amien. Garut: Karima. Astiyanto, H. (2012). Filsafat Jawa. Yogyakarta: Warta Pustaka.

Ibrahim, R. (2013). Pendidikan Multikultural: Pengertian, Prinsip, dan Relevansinya dengan Tujuan PendidikanIslam. Addin Media Dialektika Ilmu Islam, Volume 7 Nomor 1, 129.

Katsir, I. (2013). Tafsir Ibnu Katsir, Terj. Abdul Ghoffar. Jakarta: Pustaka Imam Syafi'i.

Koentjaraningrat. (2001). Pengantar Antropologi. Jakarta : Rineka Cipta. 
Rachman, B. M. (2001). Islam Pruralis; Wacana Kesetaraan Kaum Beriman. Jakarta: Paramadina.

Suryana, Y. , \& Rusdiana, A. (2015). Pendidikan Multikultural. Pustaka Setia: Bandung.

Thoib, I. , \& Mukhlis. (2013). Dari Islamisasi Ilmu Menuju Pengilmuan Islam; Melawan Hegemoni Epistemologi Barat. Ulumuna; Jurnal Studi Keislaman . 
